\title{
RICHARD OWEN'S HUNTERIAN LECTURES ON COMPARATIVE ANATOMY AND PHYSIOLOGY, $1837-55$
}

\author{
NICHOLAS RUPKE*
}

In recent years, historians of biology have drawn attention to the fact that during the period 1830-59-the three decades before the publication of Darwin's Origin of species-a major change took place in biological thought in England. Teleological explanations of the Cuvierian and Paleyan kind were amended, if not entirely supplanted, by a mixture of idealist and transcendentalist philosophies. This new approach sought to explain organic diversity as variations on ideal or primitive types. Thus the significance of organic structure was no longer primarily its adaptive function, but the underlying law by which it could be reduced to a general type. In this way, organic diversity assumed a historical meaning which could be discovered by means of the study of comparative anatomy, embryonic development, and fossil succession.

Ospovat has argued that, on the basis of this change in biological thought, the naturalists of the middle part of the nineteenth century should not be divided into creationists and evolutionists, but into teleologists, who continued to toe the Paleyan line, and non-teleologists. ${ }^{1}$ Darwin belonged to the latter group, and Ospovat's division sheds new light on the cognitive side of Darwinism and as such is of philosophical value. Its historical worth, however, is limited by the fact that the two groups had little if any social reality: they did not constitute actual circles of friends or colleagues. In particular, the non-teleological group, which included such opponents of Darwin as Louis Agassiz and Richard Owen, represented merely a cluster of scientific views, not a group of collaborating naturalists.

Like Ospovat, Jacyna has emphasized the importance of idealist thought in English biology of the 1830 s and 1840 s. $^{2}$ Both authors single out Martin Barry, William Carpenter, and Owen as the main advocates of the new approach.

* Dr Nicholas A. Rupke, Wellcome Institute for the History of Medicine, 183 Euston Road, London NW1 2BP.

\footnotetext{
${ }^{1}$ Dov Ospovat, 'Perfect adaptation and teleological explanation: approaches to the problem of the history of life in the mid-nineteenth century', Studies in the History of Biology, 1978, 2: 33-56. See also, idem, 'The influence of Karl Ernst von Baer's embryology, 1828-59: a reappraisal in light of Richard Owen's and William B. Carpenter's "Palaeontological application of 'Von Baer's Law"', J. Hist. Biol., 1976, 9: 1-28; idem, The development of Darwin's theory: Natural history, natural theology, and natural selection, 1838-59, Cambridge University Press, 1981.

${ }^{2}$ L. S. Jacyna, 'The Romantic programme and the reception of cell theory in Britain', J. Hist. Biol., 1984, 17: 13-48. See also, idem, 'Principles of general physiology: the comparative dimension to British neuroscience in the 1830s and 1840s', Studies in the History of Biology, 1984, 7: 47-92.
} 


\section{N. Rupke}

According to Jacyna, they and others developed a research programme which was to a large extent inspired by the German Romantics. English idealist biology took its cue from German work in anatomy, physiology, and embryology, imbued with the speculative philosophies of both Kantian transcendentalism and the Romantic Naturphilosophie of Oken, Carus, and others. The Romantic programme served to enhance the respectability of scientific medicine, and a number of its promoters made it part of the polemics of their institutional and social self-advancement.

The "German connexion" was discussed long ago by Russell, and recently has received a boost with the publication of Rehbock's study of idealist natural history in both England and Scotland. ${ }^{3}$

By contrast, Desmond has focused attention on the "French connexion".4 His study of London zoology in the 1830 s centres on Robert Grant, who disseminated the evolutionary ideas of Lamarck and Geoffroy. A valuable feature of Desmond's writing is that he rarely, if ever, introduces a naturalist without also providing information about the man's social rank or political allegiance. Based on this socio-political criterion, Desmond sees a division between on the one hand Grant with his radical associates such as Thomas Wakley, editor of the Lancet, and on the other hand Owen, patronized by the Oxbridge establishment, of which many members were devout Paleyites. Owen's choice of biological theory, Desmond believes, was part of a strategy intended to counter Grant's radical threat.

In all these studies, Owen stands out as a major figure of nineteenth-century English biology. The different approaches of Ospovat, Jacyna, and Desmond all contribute to a full understanding of the role Owen played. In addition, Owen's commitment to idealist morphology must be studied in the wider context of the nineteenth-century British love affair with German culture and of Owen's contacts with the circles of both Coleridge and Carlyle. This paper, which is part of the prolegomena to a broader study of Owen, is restricted to his Hunterian lectures which formed the basis of his scientific reputation. Its purpose is, first, to document the lecture series; second, to present a contemporary evaluation of its significance; and third, to discuss not so much why Owen adopted certain positions of theory but why, as an employee of the Royal College of Surgeons, he was able to pursue the science of comparative anatomy-which included palaeontology-instead of having to teach a subject more directly relevant to surgical practice. In this way, Owen's scientific work is placed in the institutional and social context in which it was carried out.

TEACHING AT THE ROYAL COLLEGE OF SURGEONS

In 1799, the Company of Surgeons, which the following year was to become the Royal College of Surgeons, took over the custody of John Hunter's museum. It was

\footnotetext{
${ }^{3}$ E. S. Russell, Form and function: a contribution to the history of animal morphology, London, John Murray, 1916. Philip F. Rehbock, The philosophical naturalists: themes in early nineteenth-century biology, Madison, University of Wisconsin Press, 1983.

'Adrian Desmond, 'Robert E. Grant: the social predicament of a pre-Darwinian transmutationist', $J$. Hist. Biol., 1984, 17: 189-223; idem, 'Richard Owen's reaction to transmutation in the 1830s', Br. J. Hist. Sci., 1985, 18: 25-50. See also, idem, Archetypes and ancestors: palaeontology in Victorian London, 1850-75, London, Blond \& Briggs, 1982.
} 


\section{Richard Owen's Hunterian Lectures}

purchased by the government and entrusted to the surgeons under a number of conditions, one of which stipulated "That a course of lectures not less than twelve in number upon comparative anatomy, illustrated by the preparations, shall be given twice a year by some member of the Surgeon's Company."' Until 1837, it remained the custom to devote one course of twelve lectures to comparative anatomy, and the other course to surgery. During the period 1800-13, while a new building for the Royal College of Surgeons was under construction, virtually no lectures were delivered save one course by William Blizard and two courses by Everard Home.

In 1813, the two executors of Hunter's estate, Matthew Baillie and Home, endowed an annual oration in memory of Hunter and of others who had advanced surgery. The Royal College of Surgeons thus offered its members two lecture courses and one oration each year. Among the London surgeons who delivered the lectures or the oration were such illustrious names as John Abernethy, Benjamin Brodie, Astley Cooper, Joseph Green, and William Lawrence. Their lecturing duties came on top of busy surgical practices in the different London hospitals, and, as a result, they never held the Hunterian Professorship for very long, a few years at most. They also tended to lecture on the subject of their own specialized interest. Charles Bell, or his pupil Herbert Mayo, for example, lectured on the nervous system and the organs of sense. As a result, the College failed to provide a systematic series of lectures covering the entire range of Hunter's preparations.

In the meantime, the conservator of the Hunterian Museum, William Clift, was given an assistant conservator to help with the making of the museum catalogues. Dobson believed that Owen's appointment may have come in response to the attack on the College by Thomas Wakley. ${ }^{6}$ Owen was assistant conservator from 1827 till 1842 , and conservator till 1856 . But in 1837 , he was made the sole Hunterian Professor, and the two courses, anatomy and surgery, were combined into a single course of twenty-four lectures on comparative anatomy and physiology. This, it was believed, would turn the Hunterian Museum into an effective centre of science auxiliary to surgery. Brodie maintained in his Hunterian Oration of 1837 that Owen "will prove, as I venture to predict, a more efficient professor than any of us, who have preceded him. Thus there will be established, by means of this great museum and the lectures, a school of what may be called 'the science of life,' such as has never existed in this metropolis before, and we may reasonably conclude that this will ultimately be productive of great practical results."

In a commentary on Brodie's Oration, the Lancet reported that "the announcement of Mr. Owen's name was received with much applause."' Owen lived up to expectation and made a tremendous success of his Hunterian Professorship giving an annual course of twenty-four lectures from 1837 to 1855.

\footnotetext{
${ }^{5}$ Zachary Cope, The history of the Royal College of Surgeons of England, London, Anthony Blond, 1959 , p. 24.

- Jessie Dobson, William Clift, London, Heinemann, 1954, p. 80.

${ }^{7}$ Benjamin C. Brodie, The Hunterian Oration, delivered in the Theatre of the Royal College of Surgeons in London, on the 14th of Feburary, 1837, London, Longman, 1837, p. 35-36.

Lancet, 1836-7, i: 766.
} 


\section{N. Rupke}

OWEN'S HUNTERIAN LECTURES

Delivery

Owen's twenty-four lectures were generally delivered between 4 and 5 p.m., on Tuesdays, Thursdays, and Saturdays in March, April, and May. His audience consisted of medical students, of members of the College, visitors, members of the Council, and the President. Students had to find places in the gallery of the lecture theatre. In a letter to his mother, Owen described the event as follows:

First, the members and students assemble in the gallery and body of the theatre; then, as the clock strikes four, the honorary visitors who have previously congregated with the council in the council-room are ushered down, the President, in his robes, being preceded by the mace, which is reverently deposited on the lecture-table by the beadle, when, lastly, walks in the Professor, and then, when the clock strikes five, your obedient and affectionate son makes his bow and exit, with a much lighter heart than when he entered.'

A single, complete series of lecture courses took several years. As a result, the students benefited least from the lectures, because they could rarely find the leisure to attend more than one or two sessions. Owen complained that "with regard to those gentlemen, the students of medicine and surgery in this metropolis, to whom I have the greatest wish to impart profitable and useful isntruction, I have seen, with regret, that portions only of the extensive subject, which the fulness of its treatment compelled me to divide amongst different courses of lectures, have been listened to by successive tenants of the gallery."10

Those who came to sit "at the feet of the new Gamaliel" were by no means restricted to members of the medical profession. Among the honorary visitors who at times attended Owen's lectures were representatives of the aristocracy, of the clergy, and of the scientific élite. William Buckland, in particular, was a regular attender, "and by-and-by a Hallam, a Carlyle, and a Wilberforce might be seen there side by side with the lights of medicine and surgery." 11 Not uncommonly, the lecture theatre would be filled to overflowing. Full attendance meant hundreds of people, as can be gauged from an entry by Mantell in his Journal recording an evening lecture by Owen on fossil reptiles: "The principal Surgeons and naturalists of London were present: nearly 800 persons." 12

Although Owen did not have the lecturing talent of a Buckland or a Sedgwick, he had the reputation of being a good lecturer. The somewhat dreary technicalities that characterized his discourse appealed to the fashion of earnestness among his fellow-Victorians. The clarity of his delivery, however, was a matter of controversy. Charles Lyell apparently congratulated Owen on his delivery "saying that his voice was so clear and distinct that he could be plainly heard without effort by everyone in the room."13 A few years later, however, several correspondents wrote to the Lancet complaining about his inaudibility. One letter questioned "whether he is in all

\footnotetext{
${ }^{9}$ Richard Owen, The life of Richard Owen, by his grandson, London, John Murray, 1894, vol. 1, p. 111.

${ }^{10}$ Richard Owen, Lectures on the comparative anatomy and physiology of the invertebrate animals, London, Longman, 1843, p. 4.

${ }_{11} \mathrm{~J}$. Willis Clark, Old friends at Cambridge and elsewhere, London, Macmillan, 1900, p. 369.

${ }^{12}$ E. Cecil Curwen (editor), The journal of Gideon Mantell, surgeon and geologist, Oxford University Press, 1940, p. 159.

${ }^{13}$ Owen, op. cit., note 9 above, p. 112.
} 


\section{Richard Owen's Hunterian Lectures}

respects fitted to discharge the duties of a public lecturer." ${ }^{14}$ Wakley, the editor, not known for his friendship with Owen, commented sardonically that it is useless for an orator to possess a head full of knowledge if he does not at regular intervals fill up his lungs with air. Another correspondent added to the tone of hostility by reminding the readers that Owen was perfectly capable of producing a stentorian voice when confronting an opponent at a meeting of the Royal Society. ${ }^{15}$

In addition to his Hunterian Lectures, Owen gave many talks to the Royal Society, the Geological Society, the Zoological Society, to the annual gathering of the British Association, and to several other metropolitan and provincial institutions and societies. During his tenure as Hunterian Professor, Owen published over two hundred scientific papers. The hard core of all these presentations remained the Hunterian Lectures, which excelled in detail and systematic arrangement.

\section{Structure of the series}

Owen's lectures were based on his catalogue work. His initial appointment had been for the purpose of working on the physiological catalogue, which, in its five volumes, was a masterpiece of its kind. According to Dobson, Owen's catalogue was a masterly interpretation of Hunter's views and aims. ${ }^{16}$ This catalogue was followed by several others dealing with the osteological and fossil part of the Hunterian Collection (Table 1). The original number of preparations was augmented by donations, purchases, exchanges of specimens, and by the animals that died in the Gardens of the Zoological Society, which Owen was allowed to dissect. Other specimens came to the Museum from the colonies and as the result of expeditions. Both Darwin and Livingstone, for example, provided Owen with exotic and rare specimens.

\section{TABLE 1. HUNTERIAN MUSEUM CATALOGUES PREPARED BY RICHARD OWEN}

Descriptive and illustrated catalogue of the physiological series of comparative anatomy contained in the Museum of the Royal College of Surgeons in London

1832: Vol. 1, Organs of motion and digestion (2nd ed., 1852)

1834: Vol. 2, Absorbent, circulating, respiratory and urinary systems

1835: Vol. 3, Pt 1, Nervous system and organs of sense

1836: Pt 2, Connective and tegumentary systems

1838: Vol. 4, Organs of generation

1840: Vol. 5, Products of generation

1845: Descriptive and illustrated catalogue of the fossil organic remains of mammalia and aves

1845: Synopsis of the arrangement of the preparations in the Museum of the Royal College of Surgeons of England (2nd ed., 1850)

1853: Descriptive catalogue of the osteological series contained in the Museum of the Royal College of Surgeons of England

Vol. 1, Pisces, reptilia, aves, marsupialia

Vol. 2, Mammalia placentalia

Descriptive and illustrated catalogue of the fossil organic remains of

1854: Reptilia and pisces

1856: Invertebrata

${ }^{14}$ Lancet, 1848 , i: 343.

${ }^{15}$ Ibid., p. 374.

${ }^{16}$ Descriptive catalogue of the physiological series in the Hunterian Museum, Edinburgh, Livingstone, 1970, part 1 , p. ix. 


\section{N. Rupke}

The subject of a particular lecture course tended to be related to the subject of the catalogue that Owen was working on. The lectures for 1837-42 formed the first complete series, subdivided according to the physiological catalogue, and based on the Hunterian system of comparing organs and systems. But from 1843, Owen no longer used this criterion, subdividing his material according to the different classes of animals. Comparing organs had its uses, but, Owen argued:

The combinations of all the constitutent organs in one animal must likewise be studied; and these combinations, with the principles governing them, or the correlations of organs, must be traced and compared in all their varieties throughout the animal kingdom. ${ }^{17}$

In short, as my previous courses of Hunterian Lectures, agreeably with the arrangement of the Hunterian Collection, have treated of comparative anatomy according to the organs, in the ascending order, so, in the present course, comparative anatomy will be considered according to the class of animals, and also in the ascending scale. ${ }^{18}$

This new arrangement of the material marked a level of maturity in Owen as Hunterian Professor. The lectures given in 1843 formed the first course to be published. These and the lectures of the year 1846 appeared in print based on the notes taken by William White Cooper, a surgeon-oculist who combined a kindly character with admiration for Owen. From 1848, Owen published every year a synopsis of his lectures, impressive for their detailed and systematic arrangement of topics. The Edinburgh New Philosophical Journal actually printed one of these. ${ }^{19}$ The lectures formed the basis for a number of major publications (Table 2), the Odontography, for example. Both the Lancet and the Medical Times occasionally reported Owen's lectures, especially those on the nervous system and on generation and development (Table 2). One spin-off from the latter course was his booklet on Parthenogenesis.

Through the 1840s, Owen's main interest changed from physiology to osteology and palaeontology. At the same time, his theoretical position began to drift away from the functionalism of Hunter and of the Cuvierian tradition, and to adopt a transcendentalist position which sees in the morphology of animals an inner architectural logic, quite apart from its functional aspects. Owen's main theoretical work was On the archetype and homologies of the vertebrate skeleton, published in 1848.

\section{CONTEMPORARY SIGNIFICANCE}

\section{Broderip's view}

Our view of Owen's significance has to some extent been limited by the window of T. H. Huxley's essay on 'Owen's position in the history of anatomical science', added to the Life of Richard Owen (1894). The two men had been adversaries and had lived on different sides of the Darwinian controversy: Huxley as one of "Darwin's bulldogs", Owen as England's best-known opponent of "natural selection". Huxley maintained that Owen's published Lectures $(1843 ; 1846)$ were inferior as a textbook to the Lehrbuch der vergleichenden Anatomie (1846-48) by C.T.E. von Siebold and H. Stannius. Although Huxley endeavoured "to do justice to the great and solid

\footnotetext{
${ }^{17}$ Owen, op. cit., note 10 above, p. 6.

18 Ibid.

${ }^{19}$ Edinb. new philosoph. J., 1851, 50: 329-334.
} 


\section{Richard Owen's Hunterian Lectures}

\section{TABLE 2. RICHARD OWEN'S HUNTERIAN LECTURES}

1837: History of comparative anatomy and physiology; classification; blood; muscles; bones and teeth (Several of these lectures were written up in William Clift's hand, with additions and emendations by Owen.)

1838: Digestive and circulatory systems: digestion; absorption; circulation; respiration (Written up from lecture notes by William White Cooper, and corrected by Owen.)

1839: Excretory and tegumentary systems: excretion and renals; skin and teeth (Written up from lecture notes by Cooper, and corrected by Owen. Part of the 1837-39 lecture material was incorporated in Owen's Odontography, 1840-45.)

1840: The comparative anatomy of the generative organs and the development of the ovum and foetus in the different classes of animals

(Some of the lectures were reported in the Lancet, 1840.)

1841: Comparative and fossil osteology

1842: On the comparative anatomy and physiology of the nervous system (Reported in the Medical Times, 1842-43.)

1843: On the comparative anatomy and physiology of the invertebrate animals (Published from notes taken by Cooper $(1843 ; 2$ nd ed., 1855). Some of the lectures were reported in the Medical Times, 1843.)

1844: On the comparative anatomy and physiology of the vertebrate animals

1845: The organisation of the invertebrate animals [?]

1846: On the osteology and neurology of the vertebrate animals

(Published in part from notes taken by Cooper: Lectures on the comparative anatomy and physiology of the vertebrate animals, delivered at the Royal College of Surgeons, in 1844 and 1846. Part 1, fishes, 1846.)

1847: Continued from 1846 [?]

1848: On the comparative anatomy and physiology of the vertebrated animals with warm blood (This lecture course was repeated in 1854. Some of it was reported in the Lancet, 1848. The lectures of 1844-48 formed the basis for Owen's On the archetype and homologies of the vertebrate skeleton, 1848.)

1849: On the generation and development of the invertebrated animals

(These lectures appeared verbatim in the Medical Times, 1848-50; and in part in the Lancet, 1849. The first two lectures were published separately: On parthenogenesis, 1849.)

1850: On the generation and development of the vertebrated animals (In part reported in the Lancet, 1850.)

1851: On comparative osteology

(Similar to the lecture course of 1841.)

1852: On the anatomy and physiology of the invertebrate animals

(Similar to the lectures of 1843 , though updated.)

1853: On the anatomy and physiology of fishes and reptiles

1854: On the comparative anatomy and physiology of the vertebrated animals with warm blood (A repetition of the lectures for 1848. The last lecture, 'Comparison of the apes or anthropoid quadrumana with man', was published verbatim in the Medical Times and Gazette, 1854. The lectures for 1842 and 1853-54 formed the basis for Owen's On the anatomy of vertebrates ( 3 vols., 1866-68).)

1855: On the structure and habits of extinct vertebrate animals, illustraterd by the Hunterian series of fossil remains

(The first three lectures were published in Essays and observations by John Hunter, edited by Owen ( 2 vols., 1861).)

1856: Lectures suspended 


\section{N. Rupke}

achievements in Comparative Anatomy and Palaeontology"20 of his former enemy, he denigrated these by stating: “Obvious as are the merits of Owen's anatomical and palaeontological work to every expert, it is necessary to be an expert to discern them."21 Moreover, Huxley dismissed Owen's theoretical contributions to anatomy; all that these had accomplished was to have contributed to an "awakening attention to the higher problems of morphology in this country". ${ }^{22}$

A far more appreciative portrayal of Owen's importance was given by William John Broderip (1789-1859), during Owen's heyday as Hunterian Professor. It came in the form of two fairly lengthy reviews for the Quarterly Review, 'Progress of comparative anatomy' (1852), and 'Generalizations of comparative anatomy' (1853). Together, these two essays discussed no fewer than twenty-five of Owen's publications: catalogues, lectures, a number of monographs, etc.

Broderip, although a lawyer, was an enthusiastic collector of natural objects. His conchological cabinet was unrivalled. He was a generous and humane man who liked to encourage others in their scientific pursuits. Buckland attributed his initiation in geology to Broderip, who had also encouraged young Louis Agassiz and made him known to the British public through an article in the Quarterly Review. ${ }^{23}$ Like Buckland, Broderip was a regular attender at Owen's lectures, and the two men became friends. When Broderip published his Zoological recreations (1847), a collection of "curiosities of natural history", he dedicated the book to Owen. In return, Owen wrote a favourable review of it for the Quarterly Review, ${ }^{24}$ and he dedicated his own major work On the archetype to Broderip, "acknowledging your excellent guidance by which my early studies in Zoology were facilitated". Broderip obliged by writing the aforementioned reviews of Owen's oeuvre.

This was particuarly gratifying to Owen, because the reviewing magazines tended to ignore his rather specialized and opaquely written books. After Broderip's death, Owen had to stoop to reviewing his own books in order to get these mentioned in the major periodicals. In his review of Darwin's Origin of species for the Edinburgh Review, Owen included three of his own books, and he did the same in a later essay on 'Ancient animals in South America'.25

It must be emphasized that Broderip's summation and assessment of Owen's work was not necessarily more disinterested than the later review by Huxley. As Desmond points out, ${ }^{26}$ Broderip, an Oxonian by education and a member of London's legal establishment, looked upon Owen to do his scientific bidding. It is clear, for example, that the appreciative character of Broderip's portrayal was in part the result of the anti-evolutionary applicability of Owen's work. Broderip was, to some extent, canvassing for Owen. But his reviews have the advantage of being pre-Darwinian,

\footnotetext{
${ }^{20}$ Owen, op. cit., note 9 above, pp. 331-332.

${ }^{21}$ Ibid., p. 332.

22 Ibid., p. 321 .

${ }^{23}$ [W. J. Broderip], 'Agassiz on fossil fish', Quart. Rev., 1836, 55: 433-445.

24 [Richard Owen], 'Broderip's zoological recreations', ibid., 1847, 82: 119-142.

${ }^{25}$ [Richard Owen], 'Darwin on the origin of species', Edinb. Rev., 1860, 111: 487-532. [Idem],

'Ancient animals in South America', ibid., 1882, 155: 186-204.

${ }^{26}$ Desmond (1985), op. cit., note 4 above.
} 


\section{Richard Owen's Hunterian Lectures}

unlike Huxley's later evaluation. They represent the fullest available, contemporary account of Owen's significance in a major interdisciplinary review magazine.

Broderip divided Owen's achievements into four groups: (1) improvements in the classification of animals; (2) the reintroduction of the microscope as an essential tool in anatomical and physiological research; (3) contributions to palaeontology; and (4) the formulation of general laws of animal morphology. ${ }^{27}$

Owen's classificatory work was mainly concerned with vertebrate animals. The prestigious areas of study were effectively determined by the imperfections in Cuvier's classes, the Regne animal and the Ossemens fossiles. The study of fishes, especially the fossil ones, had already been appropriated by Agassiz. Accordingly, Owen's interest was focused on the other vertebrate classes, reptiles, birds, and mammals.

The precise taxonomic affinity of the poorly known marsupials and monotremes from Australia and New Zealand was a question of fierce contention. Owen's connexions overseas and at the Zoological Gardens provided him with the opportunity to study these apparently transitional groups. He described the anatomy of the opossum and wombat, and even the process of a kangaroo's birth. Furthermore, Owen conclusively established that Ornithorhynchus paradoxus, the sensationally mixed-featured monotremous animal, was, in fact, mammalian and ovoviviparous. He classified the Marsupialia and Monotremata as two orders of a mammalian subclass.

Broderip commented that it had been the fashion among medical lecturers to decry the trustworthiness of microscopical observations. During the 1830 s, however, C. G. Ehrenberg created a sensation with his Die Infusionsthierchen als volkommene Organismen (1838), and Owen confidently made use of the microscope in his own work. He demonstrated the existence of Entophyta and Entozoa, in particular the human parasite Trichina spiralis which infests the muscles. More substantially, the microscope aided in Owen's Odontography, in which he presented a theory of the growth of teeth and the use of their microscopical features for identification and classification. Owen was co-founder and first President of the Microscopical Society of London (established in 1840).

The pinnacle of Owen's fame was his palaeontology. There was nothing unusual in this. The study of fossils had traditionally been part of comparative anatomy. In Germany, Blumenbach had used his medical chair to contribute to the study of both living and extinct forms of life. In France, Cuvier's Ossemens fossiles had been the logical successor to his Leçons d'anatomie comparée. And in England, Hunter had inspired some of his pupils to combine the study of living and fossil species. Among these pupils were, most notably, Home and James Parkinson. Clift was often called upon by his geological colleagues to identify fossil bones or teeth. After all, without a systematic knowledge of living species even the fact of extinction could not have been established, let alone extinct species identified.

Owen was drawn into palaeontology when presented with some mammalian fossils

${ }^{27}$ [W. J. Broderip], 'Progress of comparative anatomy', Quart. Rev., 1851, 90: 362-413. 


\title{
N. Rupke
}

brought back by Darwin from his Beagle voyage to South America. In 1839, the fragment of the shaft of a femur from New Zealand came into Owen's possession, from which he deduced the former existence of a gigantic wingless bird which he named Dinornis. Later discoveries proved him right, and the Dinornis became a widely cited example of the successful application of anatomical skill to the fragmentary evidence of fossils. It appeared to confirm the Cuvierian dictum that a single fossil bone suffices to reconstruct the entire animal. Broderip recalled:

\begin{abstract}
We well remember seeing this fragment of the shaft of a femur when it first arrived, and hearing the opinion of the Professor as to the bird to which it must have belonged. He took, in our presence, a piece of paper, and drew the outline of what he conceived to be the complete bone. The fragment, from which alone he deduced his conclusions, was six inches in length and five inches and a half in its smallest circumference; both extremities had been broken off. When a perfect bone arrived, and was laid on the paper, it fitted the outline exactly. ${ }^{23}$
\end{abstract}

Owen's large collection of fossils and his aptitude for systematic work formed the basis for a number of classic monographs. Already by the end of the 1830 s, Owen's contributions to the study of vertebrate fossils had become so numerous that when Buckland, in his anniversary address to the Geological Society, summed up the discoveries of 1839 , almost the entire section on palaeontology dealt with Owen's work. ${ }^{29}$ The British Association provided him with funds to write a Report on British fossil reptiles $(1839 ; 1841)$ and on British fossil mammals $(1842 ; 1843)$. In the reptile report he coined the term "dinosaur" ${ }^{30}$ With the same systematic discipline, he described the fossil sloth Mylodon, the giant armadillo Glyptodon, and although the Megatherium had received much attention before from Buckland and others, Owen wrote the definitive memoir on Megatheroid quadrupeds (1842), published under the auspices of the Royal College of Surgeons.

Owen's palaeontological triumphs received considerable press coverage. Upon completion of his reptile report to the British Association, the Literary Gazette devoted over twenty densely printed columns to this event, and it reported: "the eulogies bestowed upon this paper at its conclusion were felt by all the audience to be most justly merited; and when Dr. Buckland happily characterised its author as a worthy successor of Cuvier, a general burst of applause broke from every part of the audience." ${ }^{31}$

\section{Theoretical implications}

To Broderip, "the most curious and profound series of his writings"32 were Owen's books on The archetype (1848), on The nature of limbs (1849), and on Parthenogenesis (1849). These books were spin-offs from his lectures. The first two were based on his work on the osteological catalogue of some one thousand pages and nearly six thousand specimens. Although Broderip knew that Owen's ideas were

\footnotetext{
${ }^{28}$ Ibid., p. 402.

${ }^{20}$ William Buckland, 'Address to the Geological Society, delivered at the anniversary, on the 21 st of February, 1840', Proc. Geol. Soc. Lond., 1842, 3: 210-267.

${ }^{30}$ Richard Owen, 'Report on British fossil reptiles', Rep. Br. Ass. Advancement Sci., 1839, pp. 13-126; 1841, pp. 60-204.

${ }^{31}$ Literary Gazette, 14 August 1841, pp. 513-519.

32 [W. J. Broderip], 'Generalizations of comparative anatomy', Quart. Rev., 1853, 93: 46-83, see p. 47.
} 


\title{
Richard Owen's Hunterian Lectures
}

not entirely new, and that his protégé was entangled in acrimonious priority squabbles, he argued that Owen's contributions were "new at least in the best sense as being the result of strict induction".33

Owen's theoretical speculations took place against the background of the clash between the functionalism of Cuvier and the structuralism of Geoffroy. Owen liked to present himself as something of a mediator between the two schools. Abbreviated lecture notes for his course in 1841 stated: "An organ never thoroughly known 'till both teleological and morphological relations fully known." With respect to the archetype and homologies of the vertebrate skeleton, Owen wrote to Benjamin Silliman:

\begin{abstract}
You may remember the condition in which this philosphical department of anatomy was left by the great Cuvier and Geoffroy, and the discussions which unhappily tended to sever those estimable men in the latter period of their lives. The result was the formation of two schools or parties in the French world of anatomy, and subsequently the facts and arguments bearing upon these transcendental questions have been viewed in Paris through the prism of such party feeling. [But, Owen continued,] The chief and most cherished labour and reflections of many past years have been devoted by me to the acquisition of such truths as might lie at the bottom of the well into which this Philosophy of Anatomy seemed to have sunk after the departure of the great luminaries of the Jardin des Plantes. ${ }^{35}$
\end{abstract}

Owen believed that the skeleton of all vertebrate animals can be reduced to an ideal archetype, and he actually constructed such an archetype. Thus the main reason for the presence of an identical morphological feature in different species does not derive from its function, but from the architectural logic according to which a particular species can be envisaged to derive from the archetype. In theistic terms, the archetype is an architectural plan in the Divine Mind.

In conjunction with this notion, Owen was the first to distinguish clearly between analogous and homologous parts of organisms. Although the notion of homology had been vaguely used before, e.g. by Hugh Edwin Strickland, ${ }^{36}$ Owen gave it the clarity which the breadth and depth of his systematic knowledge made possible. Organs, or parts of them, are analogous when they have the same function, whether morphologically identical or not. Homologous parts are morphologically identical, but can be functionally different, like the vertebrate fore-limb which is an arm in man, a leg in most animals, and a wing in birds. Owen distinguished three kinds of homology, namely general homology ( correspondence of an organ with its ideal element in the archetype), special homology (corresponding organs in different species), and serial homology (the repetition of a single archetypal element in one and the same species). An example of the latter is the vertebral column, and Owen believed that even the skull is constructed from vertebral elements.

This represented a major break with the dominant tradition of English anatomy, which had been emphatically Cuvierian. As mentioned in the introduction, the new work of Ospovat, Jacyna, Desmond, Rehbock, and others suggests that Owen was by no means alone in undermining Cuvierian functionalism in Britain, and that others

${ }^{33}$ Ibid., p. 82.

${ }^{34}$ Lecture 1, 30 March 1841, notes for lectures, British Museum (Natural History), General Library.

${ }^{35}$ George P. Fisher, Life of Benjamin Silliman, New York, Scribner, 1866, vol. 2, p. 172.

${ }^{36}$ See Hans Haupt, 'Das Homologieprinzip bei Richard Owen', Sudhoffs Archiv, 1933, 28: 142-228. See also, Russell, op. cit., note 3 above, pp. 102-112. 


\title{
N. Rupke
}

such as Barry, Carpenter, and Knox were engaged in a similar revisionism. Essentially, Cuvier's functionalism explained the presence of an organ on the basis of "the principle of the conditions of existence". Thus functionalist epistemology focused on the adaptation of organisms to their environment. This particular focus was also that of Paleyan natural theology which drew its examples of design in nature from adaptations. ${ }^{37}$ Much of the series of Bridgewater Treatises (1832-36) was based on this, written, among others, by eminent medical men such as John Kidd, William Prout, and Peter Mark Roget.

From among Owen's immediate circle, Bell and Buckland also had followed the Cuvierian line in their respective treatises. Bell could hardly have been more explicit; in an appendix 'On the position of the head of animals, and its relation to the spine; to illustrate the proposition, that all parts of the skeleton are correlated, in adaptation to their functions', he stated:

\begin{abstract}
I hope that I have now gone far enough to prove that where uniformity is preserved in the shape of any part of the skeleton, it depends on the permanence in the function of the organ. In certain respects the head and spine are persistent in their forms; but that is merely because the brain and spinal marrow contained within the skull and vertebral column do not vary, except in point of relative size. As regards the application of the bones of the face to be instruments for obtaining food, for attack, or defence, they are ever curiously changed in their processes and articulations, in accommodation to the numerous different modes of using the parts. In fine, we may observe, that there never takes place any modification in the form of the parts of the body, - whether in the forehead, occiput, jaws, teeth, spine, pelvis, or extremities, - without a corresponding adaptation extending through the whole skeleton. ${ }^{38}$
\end{abstract}

There could scarcely have been a more explicit formulation of Cuvierian functionalism and rejection of the vertebral theory of the skull. Bell had been Owen's immediate predecessor as Hunterian Professor at the Royal College of Surgeons and in 1837 , in his first course of lectures, Owen himself had been cautiously critical of the transcendentalist school:

But what is really gained by propositions such as we have adduced? or by stating that all animal organization is reducible to one primitive form or plan? What would be thought of the geometrician, who, because all figures are modifications of the simple mathematical line, should gravely advocate their unity of composition, and put forth the observation as one of high philosophical importance? ${ }^{39}$

Although Owen never went as far as some of the Continental transcendentalist morphologists (his archetype was that of vertebrates, not of all animals; he did not believe that the embryo of higher animals recapitulates the adult stages of lower ones, but followed von Baer's "Law of progression from the general to the particular"40) the period 1841-49 saw Owen come out in explicit support for the transcendental school. In his lectures for 1841 , he objected to the position which Bell had taken. And in the second published volume of lectures, Owen defined his purpose as follows:

\footnotetext{
${ }^{37}$ See N. A. Rupke, The great chain of history, Oxford, Clarendon Press, 1983, pp. 233-248.

${ }^{38}$ Charles Bell, The hand; its mechanism and vital endowments, as evincing design, 6th ed., London, Murray, 1860 , p. 226.

${ }^{39}$ Lecture 2, 1837, p. 95; Owen Papers, Royal College of Surgeons.

${ }^{40}$ [Broderip], op. cit., note 32 above, pp. 48-56.
} 


\section{Richard Owen's Hunterian Lectures}

To determine the parts of the vertebrate skeleton which are most constant; to trace their general, serial, and special homologies, under all the various modifications by which they are adapted to the several modes and spheres, and grades of existence of the different species, should be the great aim of osteological science; as being that which will reduce its facts to the most natural order, and their exposition to the simplest expression. ${ }^{41}$

Owen did pay lip service to Paley, because he could not dispense with the argument from design. After all, this was the main argument used in opposition to pre-Darwinian theories of transmutation. Broderip, who took trouble to point out the anti-evolutionary implications of Owen's work, made an effort also to rescue as much as possible of what transcendentalism had left of the design argument. Owen, he maintained, "develops a teleology of a higher order than that of Cuvier. Far from giving support to the transmutational, pantheistic, or any other forms of Atheism, the conclusions of the homologist, being based on rigorous deductions from carefully-observed facts, furnish new arguments in support of the highest attainable truths." ${ }^{42}$

As Desmond shows, ${ }^{43}$ it was politically undesirable for Owen to ally himself with Cuvier's detractors at the Jardin des Plantes, whether with Geoffroy or Henri de Blainville. Instead, he allied himself with the German transcendentalists, whose ideas had become locally fashionable in the circle of Coleridge and, later, of Carlyle. Owen was particularly interested in Lorenz Oken, whose Lehrbuch der Naturphilosophie he was instrumental in having translated (1847); in addition, Owen wrote the entry 'Oken' for the Encyclopaedia Britannica. He met Oken in 1838, and in 1844, Owen also got to know Carl Gustav Carus whose Von den Ur-Theilen des Knochen- und Schalengerüstes (1828) had formed part of the inspiration for his work on archetypes.

These are mere hints at the reasons behind Owen's shift from a Cuvierian to a more transcendentalist stance. A full study of these reasons will be reserved for a later paper.

\section{SCIENTIFIC MEDICINE AND SOCIAL STATUS}

\section{Pure science}

In the course of a few decades, the Hunterian Museum gained an international reputation, both for its collections and for the lectures and publications by Owen. London interiors (1841-4) stated: "The Hunterian Museum is, as it were, a treasury of experience, a storehouse of facts in a visible and palpable form, to which the young medical student may resort to increase, and the old one to refresh, his knowledge."44 Thomas Hosmer Shepherd, who drew a number of the illustrations for London interiors, sketched a striking picture of the inside of the Hunterian Museum (Fig. 1), showing Owen surrounded by a number of visitors amidst an impressive display of skeletons, most dramatically of some mammalian fossils (Fig. 2).

\footnotetext{
${ }^{4}$ Richard Owen, Lectures on the comparative anatomy and physiology of the vertebrate animals, London, Longman, 1846, p. 145. See also, Edinb. new philosoph. J., 1847, 42: 216-227.

12 [Broderip], op. cit., note 32 above, p. 80.

${ }^{43}$ Desmond (1985), op. cit., note 4 above.

"London interiors: a grand national exhibition of the religious, regal, and civic solemnities, public amusements, scientific meetings, and commercial scenes of the British capital, London, Joseph Mead, $1841-44$, p. 129.
} 


\title{
N. Rupke
}

In 1844, Carl Gustav Carus, personal physician to the King of Saxony, visited Britain. His first visit in London was to the Hunterian Museum in order to meet Owen, whom he described in his England und Schottland im Jahre 1844 as "its director, augmenter and interpreter".45 Carus was especially impressed by Owen's palaeontological discoveries and by the fossil bones in the Museum:

\begin{abstract}
the most important specimens are displayed in a large hall with skylight and two galleries surrounding the upper parts of the hall. Right at the entrance I was impressed by very rare fossil creatures. On the right was the great armadillo from Buenos Aires, Glyptodon clavipes, looking almost like an immense egg the size of a large kettle-drum. Opposite on the left is the gigantic sloth-like creature, Mylodon robustus, with bird-like pelvis and coarse and osseous structure, displayed climbing up a tree trunk. At the other end of the hall a tall elephant skeleton towers above all else. But all around are the rarest specimens in profusion, most outstanding the remains of that immense New Zealand prehistoric bird, Dinornis, more than half again the size of an ostrich, and which seems amongst present-day birds most closely-related to the New Holland (the mainland of Australia) curiosity, the Apteryx. ${ }^{46}$
\end{abstract}

Both Shepherd's picture of the Hunterian Museum and Carus's description demonstrated the extent to which the fame of the collection had come to rest on the osteological specimens, especially the vertebrate fossils. This not only reflected Owen's interest, but also indicated a commitment of the Royal College of Surgeons to comparative anatomy and palaeontology. After all, a lot of money was spent on acquiring and casting the skeletal treasures: the Megatherium and the elephant, for example, each cost two hundred pounds; the Mylodon was even more expensive, over three hundred pounds; a few loose bones of the Dinornis were bought for fifty pounds; and plaster casts of these ranged in price from a dozen to over one hundred pounds. ${ }^{47}$ To these expenses must be added the considerable costs of publishing such monographs by Owen as the Memoir on the pearly nautilus (1832), or his Description of the skeleton of an extinct gigantic sloth (1842), each published by the Royal College of Surgeons at a cost of several hundred pounds.

How could this have happened? Why did the Royal College of Surgeons invest so heavily, both financially and intellectually, in a pure science, comparative anatomy, and especially in its most esoteric branches of osteology and palaeontology? The acquisitions policy of the Museum, and the duties of its conservator and of the Hunterian Professor were increasingly focused on the purely scientific interpretation of the Hunterian legacy.

This commitment to comparative anatomy and palaeontological interests was not restricted to Owen's period of tenure as Hunterian Professor, but had evinced itself long before. Two men in particular had preoccupied themselves with comparative anatomy, Everard Home (1756-1832) and Anthony Carlisle (1768-1840), both pupils of Hunter. Home's Lectures on comparative anatomy (6 volumes, 1814-28) were published by the Royal College of Surgeons, although they were more a

\footnotetext{
${ }^{45}$ H. J. Hambury, 'A visit of professor Carus of Dresden to the Royal College of Surgeons in 1844', Ann. R. Coll. Surg. Eng., 1956, 18: 262-265, see p. 263. See also, Max Neuburger, 'C.G. Carus on the state of medicine in Britain in 1844', in E. A. Underwood (editor), Science, medicine and history. Essays in honour of Charles Singer, Oxford University Press, 1953, vol. 2, pp. 263-273.

${ }^{46}$ Hambury, op. cit., note 45 above, p. 264.

${ }^{47}$ Arthur Keith, 'Abstract of minutes of the Museum Committee. Royal College of Surgeons of England. From 1800-1907’, unpublished typescript, 1908, Hunterian Museum, passim.
} 


\section{Richard Owen's Hunterian Lectures}

collection of "curiosities of natural history" than a systematic textbook of anatomy. But Home's reputation suffered after he destroyed many of Hunter's manuscript papers, and the suspicion was raised that a number of his own papers depended for much of their merit on Hunter's unpublished writings. The Lancet bluntly referred to "the supposed labours of the literary robber Home". ${ }^{48}$

Carlisle, who was twice elected President of the Royal College of Surgeons (1828; 1837), also delivered two Hunterian Orations $(1820 ; 1826)$. Both were impassioned pleas for making surgery more scientific by promoting comparative anatomy:

The causes which rule the complex phenomena of living bodies are not apparent in any single species of creature; but the interesting diversity of textures and compositions dispersed through the animal race, are so many connecting links, that they almost seem designed to tempt the curiosity of man, and to lead his rational faculties into these scientific considerations which must eventually render our Art both more profound and more efficacious. ${ }^{49}$

In his daring oration of 1826 , Carlisle argued with equal conviction that a surgeon's education ought to proceed from the side of the dissecting table to that of the operating table. He illustrated his views of the interest of comparative anatomy by restricting his address to the anatomy of "the common eatable Oyster". The Lancet ridiculed him as "Sir Anthony Oyster", but Owen enjoyed a particularly good relationship with Carlisle and must have derived much support from his patron for the promotion of comparative anatomy. ${ }^{\mathbf{5 0}}$

The connexion between the College and palaeontology had existed long before Owen's arrival. Gideon Mantell, a provincial surgeon and member of the Royal College of Surgeons, had made a name for himself through his discoveries of fossils; later he attended the palaeontological lectures by Owen. James Parkinson, one of Hunter's own pupils and another surgeon-cum-palaeontologist, was awarded the first Honorary Medal of the College, in 1822, especially for his Organic remains of a former world (1804-11).

\section{Criticism}

This commitment to pure science was not left unquestioned, and, in fact, criticism, even ridicule, was expressed. The Lancet, in particular, saw it as its task, not just to call for the reform of the government of the Royal College of Surgeons, but also to urge its Hunterian Professor to devote his skill and energy "in favour of Surgery". In a scathing review of Owen's memoir on the Mylodon robustus, the Lancet sarcastically commented that this splendid tome was published "of course, for the advancement of practical surgery, and the knowledge and treatment of those diseases and accidents to which the human frame is liable, and which are taken by the College of Surgeons under its special care." 51 The quality of the work itself was not the issue, but the fact that expensive studies of the pearly nautilus or the extinct sloth should be paid for by the fees of surgeon-members:

${ }^{48}$ Lancet, 1837 , i: 766.

${ }^{49}$ Anthony Carlisle, The Hunterian Oration, delivered before the Royal College of Surgeons, on February 21,1820 , London, Longman, 1820, pp. 18-19.

${ }^{\text {so }}$ Keith, op. cit., note 47 above, p. 44.

${ }^{31}$ Lancet, 1842-3, ii: 170. 


\section{N. Rupke}

Had this work emanated from the Zoological, the Linnean, or the Geological Societies, we might have hailed its appearance with unmingled gratification. But, considering its utter worthlessness to the surgeons of Great Britain, - to the men by whose contributions this college is entirely supported, and the boundless stores of physiological and pathological treasures that are contained in the Hunterian collection, and which would be of inestimable value if placed within the reach of the general practitioner, by means of suitable publications, it can only be regarded by all conscientious men who have any concern in the matter, as a profligate expenditure of funds of the members, and a palpable misoccupation of the time and talents of their servant, the curator..$^{52}$

Equally, Owen's penchant for transcendentalist theory did not escape Wakley-inspired sarcasm. After a lecture by Owen on 'Metamorphosis and metagenesis' (1851), the Lancet printed the following irreverent 'Impromptu':

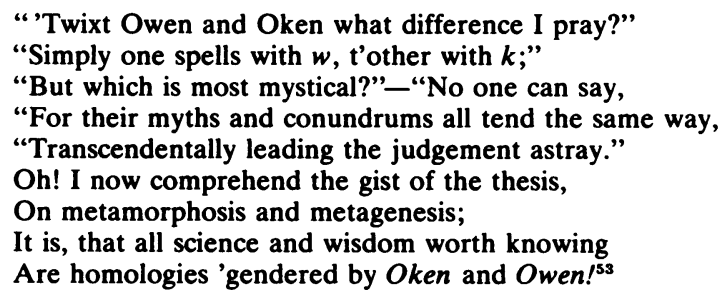

This criticism of Owen was to some extent merely the extension of Wakley's long-standing criticism of the Royal College of Surgeons as part of his attempt to change the government of the College to more democratic rule. The Lancet itself had more than once recommended the study of comparative anatomy: "It often supplies, by manifest analogies, the deficiency of direct observation in various points of the anatomy of man." 54 It also had printed on its pages the lectures on comparative anatomy by Owen's rivals, Henri de Blainville and Robert Grant. ${ }^{55}$

But inside the College too, unease was expressed in the course of the 1840s about this disproportionate interest in recent and fossil osteology. At times, the Museum Committee declined Owen's proposals for the acquisition of certain fossils, and at regular intervals it expressed criticism of Owen for spending too much time on fossils and too little on human anatomy.$^{36}$ The question thus recurs with more pertinency: "why did the Royal College of Surgeons focus its resources increasingly on comparative anatomy and on palaeontology, instead of on human and morbid anatomy or on surgery?"

The fact that Owen failed to secure elevation to the Council of the College, ostensibly because he had given up the practice of surgery, does not necessarily imply an indifference to scientific pursuits on the part of the College's ruling body, as Jacyna suggests. ${ }^{57}$ After all, restricting the control of a surgical society to surgeons does not seem unduly chauvinistic. And, although the Council drew its members

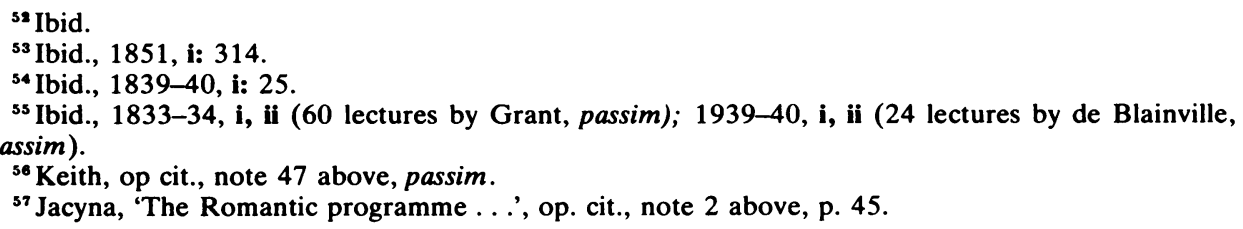




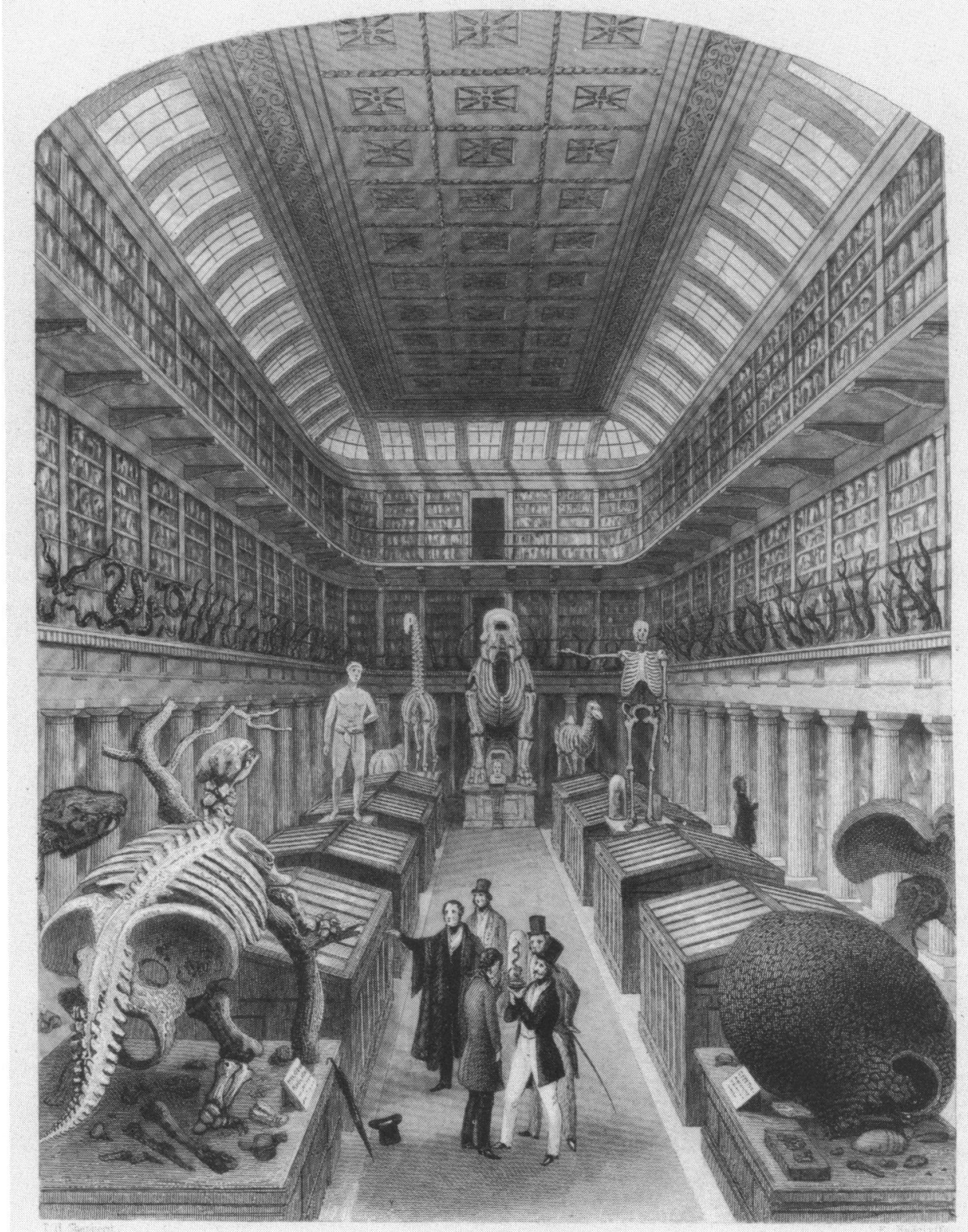

Figure 1 The exhibition hall of the Hunterian Museum. Steel engraving based on a drawing by T. H. Shepherd. 


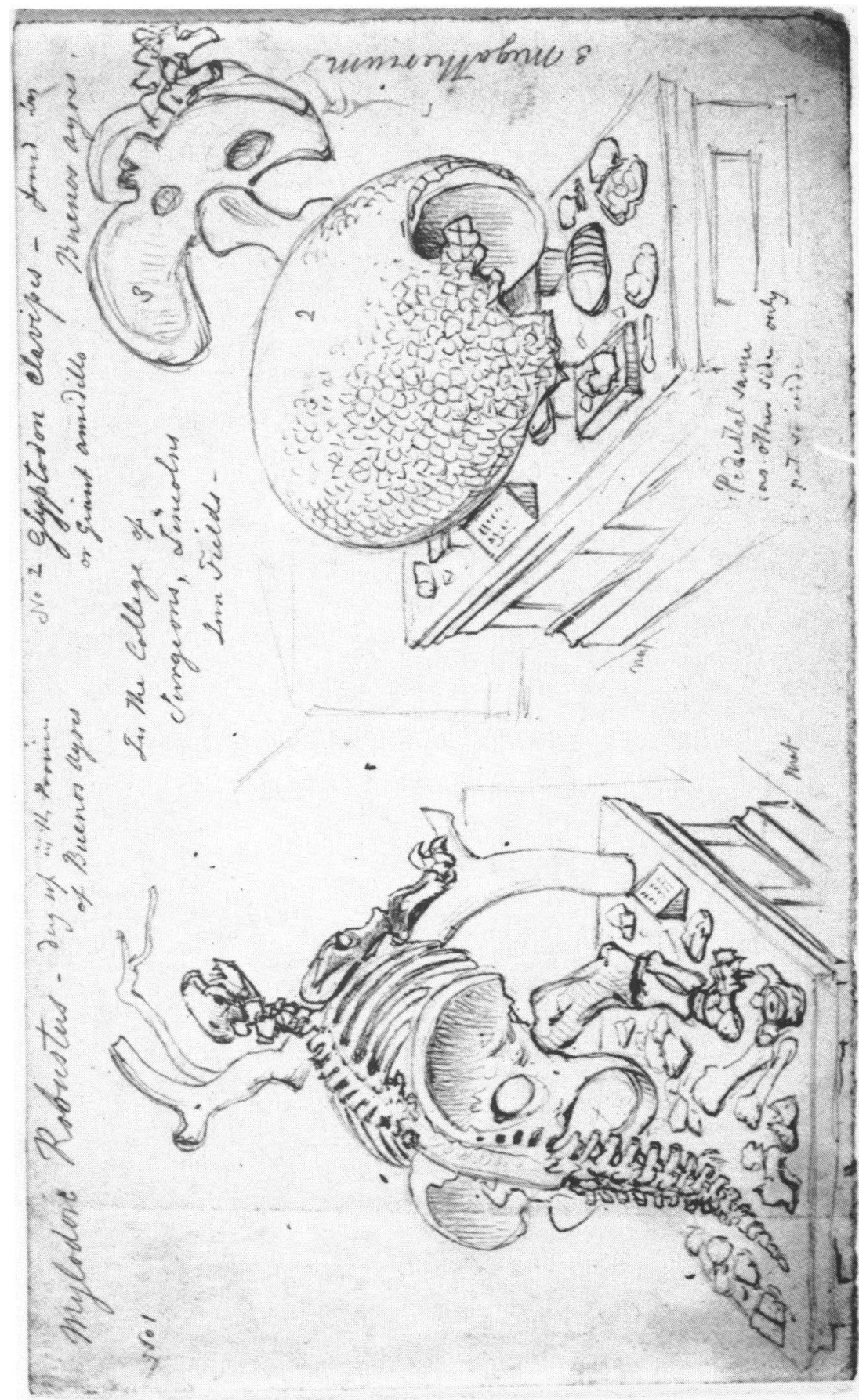




\title{
Richard Owen's Hunterian Lectures
}

from the ranks of London's hospital surgeons, the trustees of the Hunterian Collection counted among its members a number of non-surgeon-scientists, such as Herschel, Egerton, Buckland, and later also Murchison and Lyell. ${ }^{58}$

\section{Hunter's legacy}

One justification for promoting comparative anatomy was that this represented part of the Hunterian legacy. After all, Hunter's interest had ranged widely. When the Company of Surgeons assumed the charge of the Hunterian Collection in 1799, it had included some 13,682 preparations, of which more than one-quarter, 3,709, were fossils (plants, invertebrates, and vertebrates). ${ }^{59}$ The annual Hunterian Orations tended to be eulogies of Hunter and be filled with exhortations to follow in his steps. As Carlisle put it, these panegyrics were intended "To keep alive the public-minded exertions of Mr. Hunter, to cherish and to encourage those abstract researches which give the Healing Art a claim to be associated with the Sciences". ${ }^{60}$

Jacyna has argued that the way in which Hunter was portrayed by successive Hunterian Orators represented not so much an objective sketch of the man's accomplishments and talents, but a form of scientific iconolatry which served contemporary polemical purposes. ${ }^{61}$ The orators, such as Blizard, Abernethy, Carlisle, William Morris, and later James Paget, wanted to raise the social status of the members of the College, and accordingly they tailored Hunter's image to meet the social aspirations of surgeons. Owen acted no differently, and made an effort in the introductory lectures of his first course in 1837 to establish his claim as a legitimate heir to the Hunterian heritage. In Hunter, he maintained, England had possessed one of the greatest comparative anatomists:

\begin{abstract}
Had Hunter published, seriatim, his notes of the anatomy of the animals which he dissected, these contributions to comparative anatomy would not only have vied with the labours of Daubenton, as recorded in the "Histoire naturelle" of Buffon, or with those comparative dissections of Vicq d'Azyr, which are inserted in the early volumes of the "Encyclopédie méthodique", but they would have exceeded them both together. . . . Vicq d'Azyr did not carry his scalpel beyond the vertebrate series, while Hunter explored every modification of animal structure, from man down to zoophytes. ${ }^{62}$
\end{abstract}

In the last part of this quotation, however, lies the crux: Hunter had been concerned with human anatomy and surgery as well as with the dissection of animals. Why should the College wish to narrow the Hunterian legacy by focusing on the study of animals, living and extinct?

\section{Competition of the London hospitals}

Part of the answer may have been the competition which the College experienced from the London hospitals. In addition to the continuing existence of the private anatomy schools such as the Windmill Street School and the London School of

\footnotetext{
${ }^{58}$ Victor Negus, History of the Trustees of the Hunterian Collection, Edinburgh, Livingstone, 1966, passim.

${ }^{59}$ Cope, op. cit., note 5 above, pp. 304-305.

${ }^{60}$ Carlisle, op. cit., note 49 above, p. 2.

${ }^{61}$ L. S. Jacyna, 'Images of John Hunter in the nineteenth century', Hist. Sci., 1983, 21: 85-108.

${ }^{62}$ Owen, op. cit., note 39 above, p. 87.
} 


\title{
N. Rupke
}

Anatomy, the early half of the nineteenth century saw the rise of the hospitals as centres of medical education. By the time Owen resigned his Hunterian Professorship in 1856, a student could get a medical education at no fewer than eleven hospital schools, namely St. Bartholomew's, St Thomas's, Westminster, Guy's, St George's, the London, the Middlesex, Charing Cross, St Mary's, and University and King's Colleges. Each of these hospital schools offered a full programme of medical education, and opportunities for the study of morbid anatomy, midwifery, and the theory and practice of surgery with which the Hunterian Museum could not compete. ${ }^{63}$ Accordingly, Brodie justified Owen's appointment as follows:

\begin{abstract}
The wards of the hospital and the dissecting-room, will enable the diligent student to obtain an adequate knowledge of what has been already done in surgery, and to become a good practical surgeon; but those who would earn for themselves pre-eminence, by adding to our stores of knowledge and improving the science of their profession, must carry their views further, contemplating the phaenomena and laws of life, generally; not as they are exhibited in our species only, but as they exist in the whole animal creation.
\end{abstract}

It must not be left unmentioned, however, that the hospital medical schools also included comparative anatomy in the curriculum. Owen himself began his teaching career by giving "an elementary course of lectures on comparative anatomy" at St Bartholomew's Hospital in 1835. At University College, Owen's main rival, Robert Grant, published his Outlines of comparative anatomy (1835-41). At King's, Thomas Rymer Jones wrote a very popular General outline of the animal kingdom, and manual of comparative anatomy (1838-41) (dedicated to Owen). In addition, the Royal Institution offered comparative anatomy through its Fullerian Professorship. It is therefore unlikely that competition of the hospitals was anything more than a subsidiary reason for the College to have invested in comparative anatomy.

\section{Social Prestige}

The main reason for the Royal College of Surgeons to have promoted pure science in the form of comparative anatomy was that it gave badly needed prestige to its surgeon-members and to the medical profession in general.

Many Victorians were interested in science, not because it could be put to practical use, but because of the social cachet it gave to the scientists. Recent historiography of the early part of the nineteenth century has tended to diverge from traditional economic reductionism which interpreted the interest in science in terms of its supposed applicability to industrial or other material needs. In a classic study of 'The rise of the science of geology', Porter argued that the economic pressure of industry had little to do with the popularity of geological pursuits. ${ }^{65}$ Thackray, in his masterly

\footnotetext{
${ }^{63}$ See M. Jeanne Peterson, The medical profession in mid-Victorian London, Berkeley, University of California Press, 1978, pp. 12-13, 65. See also, Charles Newman, The evolution of medical education in the nineteenth century, London, Oxford University Press, 1957.

${ }^{4}$ Brodie, op. cit., note 7 above, p. 36.

${ }^{6}$ Roy Porter, 'The Industrial Revolution and the rise of the science of geology', in Mikulas Teich and Robert Young (editors), Changing perspectives in the history of science. Essays in honour of Joseph Needham, London, Heinemann, 1973, pp. 320-343.
} 


\section{Richard Owen's Hunterian Lectures}

examination of the Manchester Literary and Philosophical Society, maintained that the underlying motivation for scientific involvement was a search for social identity and status. ${ }^{66}$ And Jacyna, in his study of the nineteenth-century Hunterian Orations, emphasized that praise for Hunter as a great scientist was inspired by a desire to give new prestige to the surgical profession. ${ }^{67}$

By participating in science, socially marginal groups sought to advance their position in society. Scientific activity formed a new standard of social legitimacy, in lieu of such traditional ones as an Oxbridge education, the Church, or titled family connexions. Science may also have functioned as a vehicle for social mobility within the existing order, or have been used to defend the interests of those already well established. In a recent study, MacLeod argues that during the period 1830-50, the scientific establishment in London, like the medical establishment, sought to justify its social status by raising its intellectual character. ${ }^{68}$ It seems certain that one has to go beyond the "clinical utility" approach in explaining the attraction of pure science to surgeons.

By the early part of the nineteenth century, the medical profession presented a very unintegrated and heterogeneous picture. There were considerable differences in rank between the physicians, the surgeons, and the apothecaries; between London and the Provinces; between England and Scotland; and between an education by apprenticeship or via Oxbridge. The surgeons, in particular, suffered from the old-time association with the barbers, and as a group were held in low esteem. Surgery was regarded as little more than skilled manual labour. "Empirics" or "quacks" operated more or less freely and gave the healing profession a bad reputation. Before the Medical Act of 1858, little if any, uniformity existed in medical education.

In 1800 , the Company of Surgeons received a royal charter to become the Royal College of Surgeons in London. A new charter, in 1843, made it the Royal College of Surgeons of England. From 1822 on, the head of the College was no longer called "Master", but "President". And the new charter of 1843 provided for the élite rank of Fellow (FRCS), in addition to Member (MRCS). All these changes, Peterson believes, were symptomatic of a movement of the surgeons away from the old craft connotation to the more elevated status enjoyed by the prestigious College of Physicians. ${ }^{69}$ By improving educational standards, they hoped to raise the social character of their profession as well. In an essay for the Quarterly Review, Lyell explicitly linked scientific education and social class. If more science courses had been added to the training in surgery, this would "have induced many, from a somewhat higher class of society, to enter into that branch of the profession."

In advocating comparative anatomy, the surgeons did not entirely omit the argument of its usefulness to the practice of medicine and surgery. Both Carlisle and

\footnotetext{
'Arnold Thackray, 'Natural knowledge in cultural context: the Manchester model', Amer. hist. Rev., 1974, 79: 672-709.

${ }^{67}$ Jacyna, op. cit., note 61 above.

${ }^{68}$ Roy MacLeod, 'Whigs and savants: reflections on the reform movement in the Royal Society, $1830-48$ ', in Ian Inkster and Jack Morrell (editors), Metropolis and province, London, Hutchinson, 1983, pp. 55-90.

${ }^{69}$ Peterson, op. cit. note 63 above, p. 9.

${ }^{70}$ [Charles Lyell], State of the universities', Quart. Rev., 1827, 36: 235.
} 


\title{
N. Rupke
}

Owen, for example, argued that dissection and experiments on animals had greatly aided in the understanding of human anatomy and physiólogy. Harvey's discovery of the circulation of the blood was cited as an example. Hunter's treatise on the blood and inflammation was similarly attributed to his studies of animals. The Medical Times commented, in a review of Owen's lectures: "No one can acquire a clear insight into the physiology of the human organs, unless he have borrowed from comparative anatomy the powerful light which that interesting science can alone shed upon his researches."71

Owen particularly emphasized the importance of experiments on animals, of what later in his lifetime became known as vivisection. "Comparative anatomy is of use by enabling us to perform experiments on the lower orders of animals, which we are not in a position to perform on man, and to witness such operations performed, as it were, by Nature herself."72 In exemplification of the end of this quotation, Owen cited the organs of generation. In man, these are very complex, but the function of the different parts can be learnt by the study of animals in which particular genital parts (vesiculae seminales, prostate etc.) do not occur.

No secret was made, however, of the fact that everyone concerned saw in the teaching of comparative anatomy a way of elevating English medicine in Europe, and of raising the status of surgery in London. Some of the coryphaei of the Continental scientific world were medically trained men active in the field of comparative anatomy. Blumenbach had taught osteologia comparata as early as 1777 . His Handbuch der vergleichenden Anatomie went through several editions. Cuvier's Leçons d'anatomie comparée made him an international name. Meckel's Lehrbuch der vergleichenden Anatomie earned him the epithet "the German Cuvier". All these men were working in institutions with extensive collections, and were engaged in medical education. By comparison, in an essay published in 1826, Lyell maintained that the Royal College of Surgeons was discreditably inferior. ${ }^{73}$ And Owen stated in his introductory lectures of 1837 :

\begin{abstract}
Had the means and time been granted to Hunter to have made publick all the great results of his unexampled labours; - or had similar researches been conducted with the same spirit by his immediate successors: - would our teachers now, after a lapse of half a century have but begun to develop to their students those beautiful laws of animal development for their knowledge of which they are indebted to the labours of the professors and conductors of those noble schools of Continental Europe, where the spirit of Hunterian inquiries seems so long to have exclusively resided? ${ }^{74}$
\end{abstract}

When, by the early 1840 s, Owen's work had begun to catch up with that of his Continental colleagues, the panegyric comparisons of England's own Owen with Germany's Humboldt or France's Cuvier were loud and frequent. The Medical Times referred to "the master-hand of the most distinguished Comparative Anatomist of his country and his age." ${ }^{\prime 75}$ Broderip believed that the books by Owen, Rymer Jones, and others "augur well for the interest of medical science, and for the

\footnotetext{
${ }^{71}$ Med. Times, 1844, 10: 350.

${ }^{72}$ Ibid., 1845, 12: 116.

73 [Charles Lyell], 'Scientific institutions', Quart Rev., 1826, 34: 161.

74 Owen, op. cit., note 39 above, p. 87.

${ }^{75}$ Med. Times, 1845, 12: 46.
} 


\section{Richard Owen's Hunterian Lectures}

elevation of the attainments and character of its professors." ${ }^{\prime 76}$ Hunter's mantle had descended upon Owen, and Cuvier's prediction had come true that anatomy, one day, would have its Newton. ${ }^{\mathbf{7 7}}$

International comparisons apart, Carlisle repeatedly emphasized that the only way for the surgeons to raise their reputation in the public esteem, to be respected as "the legitimate Guardians of Health", and to protect themselves "against the invasions of cunning Pretenders", was to promote science, comparative anatomy, and physiology, "by which means the Members of our College will be gradually estranged from the Sect of Empirics, - that Sect whose circumscribed notions of medicine exclude all liberal and scientific pusuits, and leave our Faculty no better source for instruction than the blind adventures of a chance-medley experience, - a Sect so closely resembling ignorant quacks, that it needs only the addition of sordid imposture to complete the alliance."78

Anatomy not only gave dignity to surgery, it was a far more attractive subject than the courses by which students of theology or of law were introduced to their prospective professions. Owen used to point out that a medical student entered his profession by the portals of anatomy, and he "compared their good fortune in having so highly interesting a science for investigation with that of the clergy and the members of the legal profession, whose initiatory studies are of a comparatively dry and uninteresting nature." 79 A surgeon writing to the Lancet expressed delight at the large audience which Owen's lectures had, and he continued, in reference to Wakley's reform efforts: "You forced the constituted authorities to institute a better system of medical education, and thereby elevated the status of the general practitioner; so that he now ranks as a professional man, and a gentleman."80

The concurrent promotion of palaeontology was probably the clearest indication of how much the scientific teaching at the Royal College of Surgeons was motivated by a desire to gain prestige and social respectability. Obviously, whatever usefulness comparative anatomy may have had for the practice of surgery, palaeontology definitely had none. The flow of usefulness was entirely one-way, from anatomy to the study of fossils. But at that time, palaeontology was part of the cutting edge of science. The Royal Society awarded its highest honours, the Copley Medal and the Royal Medal, to Mantell and Owen for their palaeontological work. The Medical Times published an extremely favourable review of Owen's History of British fossil mammalia (1845). It acknowledged Owen's distinction, which was based, not on "birth and fortune", but on "the inborn aristocracy of talent"; "conventional distinctions of rank, must invariably yield precedence to the loftier claims of inborn power and greatness, the aristocracy of birth and fortune, to the inborn aristocracy of talent".81 In his lectures, Owen himself argued that the social status of a medical man obliged him to be knowledgeable about fossils:

\footnotetext{
${ }^{76}$ Ibid., 1844, 10: 350.

${ }^{77}$ [Broderip], op cit., note 32 above, p. 83.

${ }^{78}$ Carlisle, op. cit., note 49 above, pp. 55-56.

${ }^{79}$ Med. Times, 1845, 12: 116.

${ }^{80}$ Lancet, 1848 , i: 374 .

${ }^{81}$ Med. Times, 1845, 12: 46.
} 


\section{N. Rupke}

The increasing taste for the natural sciences, and the rapidly diffusing knowledge of zoology and geology, render it scarcely pardonable in a member of a liberal profession to be wholly unversed in them; and almost discreditable to a medical man to be unable to offer any sound opinion on a fossil coral, shell, or bone which may be submitted to his inspection, or on the other surprising phenomena of organic Nature, as the animal origin of chalk and flint, which geology from time to time educes from the dark recesses of the earth, and makes a common topic of conversation.82

\section{CONCLUSION}

When, in 1837, Owen was appointed Hunterian Professor at the Royal College of Surgeons, the subject of his lecture course - comparative anatomy and physiology had become the testing ground for one of the great scientific debates of the nineteenth century, namely the debate about the meaning of organic structure. The rich Hunterian Collection provided Owen with the opportunity to organize a uniquely thorough and systematically wide-ranging lecture series. Scientific expertise followed in its wake. His patrons and paymasters proclaimed him England's answer to Cuvier, in a self-serving effort to put the horse of his prestige to the cart of their own polemical purposes. In particular, members of the Royal College of Surgeons used their association with pure science as a means to increase the respectability of surgical work and elevate their social status. Thus Owen was able to pursue his scientific ambitions at the College's Museum and ride to scientific eminence on the back of the social inferiority feelings of his erstwhile medical colleagues.

\section{ACKNOWLEDGEMENTS}

The research on which this paper is based was made possible by a fellowship provided by the Wellcome Trust. I should like to thank Drs W. F. Bynum and Roy Porter for comments on an early draft, and Elisabeth Allen for help with the tables and illustrations.

${ }^{82}$ Owen, op. cit., note 10 above, p. 5. 